\title{
IDEA POKOJU W WYSTĄPIENIACH PAPIEŻA JANA PAWŁA II NA FORUM ONZ Z LAT 1979-1995 ORAZ W ORĘDZIACH NA ŚWIATOWY DZIEŃ POKOJU Z LAT 1979-1991
}

Streszczenie. Zimna wojna była czasem bardzo napiętych stosunków międzynarodowych. Dominował w niej konflikt pomiędzy dwoma, antagonistycznie do siebie nastawionymi blokami, skupionymi wokół Związku Radzieckiego oraz Stanów Zjednoczonych. Sytuację zaogniała nakręcająca się spirala zbrojeń, którą potęgował fakt posiadania, przez obie strony broni atomowej. Wszystko było, ze sobą tak sprzęgnięte, że nawet wydarzenia, dziejące się na peryferiach głównej areny rywalizacji, stawały się polem do starcia, przeradzającym się nieraz w otwarty konflikt sprzecznych ze sobą systemów i ideologii.

Bardzo ważna stała się inicjatywa Pawła VI, który wymyślił Światowy Dzień Pokoju, podczas, którego papież wygłaszał specjalnie przygotowane orędzie. Dzieło to kontynuował następnie Jan Paweł II i jest kultywowane do dnia dzisiejszego. Polski papież zaczerpnął rozumienie pokoju od Pawła VI, mówiąc, iż jest on równoznaczny z rozwojem. Prócz tego, papieskie postrzeganie wyróżniał holizm.

Dla Jana Pawła II sprawa światowego pokoju w okresie zimnej wojny była bardzo ważna. Nie jest to tylko stwierdzenie, ale potwierdzały je czyny: pielgrzymki, które determinowała powyższa kwestia. Papież często łączył obydwie czynności np. przemawiając dwukrotnie na forum ogólnym Organizacji Narodów Zjednoczonych. W swoich przemówieniach papież jednoznacznie dostrzegł, że w okresie zimnej wojny, sprawa światowego pokoju była permanentnie zagrożona. Na fakt ten wpływały podziały świata na bloki, wśród, których wyróżnił: Wschód-Zachód oraz Północ-Południe. Ten drugi podział, bardzo mocno łączył się z rozwojem państw i ludzi. W celu jego analizy, papież dokonał podziału na cztery światy. Rywalizacja Wschód-Zachód sama w sobie stanowiła przeszkodę dla pokoju, ale dodatkowo Jan Paweł II zaakcentował, związane z nią wyścig zbrojeń i problem nuklearny. Z aspektami militarnymi, kojarzyły się również terroryzm oraz sprawa produkcji, a przede wszystkim, handlu bronią. Ojciec Święty problem pokojowy upatrywał również w kryzysie wartości duchowych. Według niego, jeśli pokój pochodzi od Boga, to człowiek musi być w stanie przyjąć ten dar i go pielęgnować w swym sercu i sumieniu. 
Widać wyraźnie, iż zimna wojna, rozumiana jako rywalizacja bloków wschodniego i zachodniego, bardzo często przejawiała się w papieskich wypowiedziach. Stanowiła ona jeden z kluczowych, chociaż, nie jedyny, element zagrożenia światowego pokoju. Jako główną drogę do zapanowania na świecie ładu, Jan Paweł II widział dialog. Miał on zachodzić na wszystkich możliwych płaszczyznach, od największych, w relacjach międzynarodowych, do najmniejszych - międzyludzkich. Z dialogiem nierozerwalnie łączyło się inne pojęcie, które było papieską receptą na śmiercionośne zagrożenie wojną nuklearną - negocjacje. Te dwa składniki, były fundamentem do budowy pokoju światowego i mocno wyróżniały się z papieskich orędzi na Światowy Dzień Pokoju.

Niestety prócz wyrażania szerokiej aprobaty dla słów i działań papieża, czy Stolicy Apostolskiej nie szły za tym żadne dalsze działania państw. Wniosek z tego taki, iż szczytne, mądre i ciekawe idee Jana Pawła II (bo za takie były uważane, chociażby wśród gremium członków ONZ) w znacznej mierze nigdy nie zostały wcielone w życie, a świat zarówno ten z czasów pontyfikatu papieża-Polaka, jak i dzisiejszy nadal mógłby czerpać garściami z słów i nauk głoszonych przez Ojca Świętego.

Słowa kluczowe: pokój, światowy pokój, Nauka Społeczna Kościoła, Katolicka Nauka Społeczna, Stolica Apostolska, ONZ, Światowy Dzień Pokoju, papież, Jan Paweł II, USA, zimna wojna, rozbrojenie, zagrożenie nuklearne, encyklika, Sollicitudo rei socialis, Centesimus annus, wystąpienie, orędzie, Wschód-Zachód, Północ-Południe.

$\mathrm{P}$

oniższy artykuł będzie omawiał kwestie pokoju widziane oczami papieża Jana Pawła II na przestrzeni wielu lat jego pontyfikatu. Oczywiście interesujące będą te $\mathrm{z}$ czasu zimnej wojny ${ }^{1}$, bądź nawiązujące do jej trwania. W tym celu zanalizowane zostaną najważniejsze, wybrane przemówienia, homilie i orędzia wygłoszone przez Ojca Świętego. W podejmowanym rozważaniu zastosowany zostanie klucz problemowy. Pomoże to lepiej dostrzec słowa papieża w kwestii pokoju światowego. W związku z tym, zaprezentowane zostaną dwie wypowiedzi Jana Pawła II na forum Organizacji Narodów Zjednoczonych z 1979 oraz 1995 r. Orędzia papieskie wygłoszone w nowojorskiej siedzibie ONZ z punktu widzenia pokojowej polityki Stolicy Apostolskiej są niezwykle ważne. Po pierwsze dlatego, że podstawowym celem działania ONZ jest praca na rzecz światowego pokoju i przemówienia wygłoszone w tym miejscu idealnie wpisują się w tytułowe kwestie. Drugą rzeczą jest prestiż i doniosłość słów kierowanych z mównicy. Wynika to z bardzo szerokiego gremium, reprezentowanego w tej międzynarodowej organizacji. Wśród nich byli oczywiście przedstawiciele stron konfliktu zimnowojennego jak i innych o których papież wspominał. Zestawienie

${ }^{1} 0$ tym, że w omawianym okresie czasu można nadal mówić o zimnej wojnie vide: J.L. Gaddis, Zimna wojna. Historia podzielonego świata, Kraków 2007; J. Holzer, Europa zimnej wojny, Kraków 2012; W. Roszkowski, Półwiecze. Historia polityczna świata po 1945 roku, Warszawa 1998. 
przemówienia z drugiego roku pontyfikatu papieskiego, z tym wygłoszonym kilkanaście lat później, ma na celu porównanie obydwu orędzi i określenie jakie nowe kwestie Jan Paweł II poruszał w połowie dekady lat dziewięćdziesiątych. Powyższym słowom towarzyszyć będzie homilia wygłoszona w Droghedzie w Irlandii w październiku 1979 r. Wybranie tego tekstu uzasadnia fakt, iż słowa papieskie w Irlandii były wypowiedziane bezpośrednio przed wizytą w Stanach Zjednoczonych w 1979 r. Ostatnia część artykułu, związana będzie z orędziami wygłoszonymi z okazji Światowego Dnia Pokoju. Powyższe teksty Ojca Świętego obejmują okres zimnej wojny. Szczególnie w przypadku tego rodzaju źródła, zastosowanie klucza problemowego jest wskazane, gdyż pozwoli uniknąć powtórzeń oraz chaosu, które wystąpiłyby przy analizie chronologicznej.

Pozostaje sformułować jeszcze pytania, na które w poniższym artykule poszukiwane będą odpowiedzi. Po pierwsze, w jaki sposób Ojciec Święty rozumie pokój? Jakie widzi zagrożenia dla pokoju oraz przyczyny owych niebezpieczeństw? Warto też przyjrzeć się materii zimnowojennego konfliktu. Ile miejsca zajmuje w papieskich wypowiedziach, a także w jaki sposób jest on ukazywany? Należy także poszukać odpowiedzi na pytanie, jakie są zalecenia lub możliwe scenariusze, według papieża, aby pokój mógł zapanować na świecie?

Nim rozpatrywane zostaną wypowiedzi na forum ONZ, należy kilka słów poświęcić wystąpieniu w Droghedzie. Jak już wspomniano na wstępie, zanim papież udał się na pielgrzymkę do Stanów Zjednoczonych, odwiedził po drodze Irlandię. W owym czasie, teren ${ }^{2}$ kojarzony z misyjną działalnością św. Patryka ${ }^{3}$, był niestabilny ${ }^{4}$. Prócz problematyki przynależności państwowej (północ - Wielka Brytania, południe - niepodległe), zachodziła również kwestia religijna, gdzie protestanci z Ulsteru ścierali się z katolikami,

2 Jako odniesienie do państwa.

${ }^{3}$ Św. Patryk (385-461) patron Irlandii. Urodził się w rzymskiej prowincji Brytania. Mimo iż pochodził z rodziny chrześcijańskiej, raczej wychowywał się w świeckim obyciu. Został uprowadzony przez irlandzikch piratów, gdzie w niewoli pasł owce. Wtedy też powrócił do wiary chrześcijańskiej. Udało mu się uciec do Francji, gdzie kształcił się w szkołach w Erinsi i Auxserre. W 432 r. papież Celestyn I wyświęcił Patryka na biskupa, mianując go wysłannikiem do Irlandii. Na wyspie osiągał sukcesy w chrystianizacji ludności. Z postacią Patryka wiążą się dwie opowieści, pierwsza odnośnie dzwonu, zwołującego na modlitwy. Druga związana z koniczyną, za pomocą której tłumaczył ludności tajemnicę Trójcy Świętej. Założył stolicę biskupią w Armagh (dzisiejszy Ulster w Irlandii Północnej). Vide: H. Honisz, Święty Patryk - Europejczyk i patron Irlandii, https://www.deon.pl/religia/swiety-patron-dnia/ art,296,swiety-patryk-europejczyk-i-patron-irlandii.html, dostęp: 29.06.2017.

${ }^{4}$ Zaledwie 7 lat wcześniej doszło do tragicznych wydarzeń w Derry, w Irlandii Północnej, znanych pod terminem „krwawa niedziela”. 
zwolennikami niepodległej Irlandii. Irlandzka Armia Republikańska organizowała nawet zamachy terrorystyczne ${ }^{5}$. Papież przyleciał na „zieloną wyspę" 29 października 1979 r. Najpierw odwiedził Dublin, gdzie odprawił mszę, w której uczestniczyło około 1,2 mln wiernych, co w ówczesnej Irlandii stanowiło ponad 25\% całej populacji ${ }^{6}$. Miał udać się także do Ulsteru, lecz okazało się to niemożliwe, ponieważ grożono w takim wypadku strajkiem generalnym, do czego wzywał pastor protestanckich ekstremistów Ian Paisley ${ }^{7}$. Tego samego dnia Jan Paweł II odwiedził Droghede - miasteczko znajdujące się niedaleko granicy z Irlandią Północną. Miejsce to było także świadkiem straszliwej rzezi ludności w 1649 r., dokonanej przez oddziały Olivera Cromwella, pod jego osobistym dowództwem ${ }^{9}$. W tym samym okresie został zamordowany także arcybiskup Armagh, św. Oliver Plunkett, którego relikwie znajdują się w katedrze w Droghedzie ${ }^{10}$.

W homilii papież zaznaczył, iż chciał przybyć właśnie w to miejsce zanim uda się do Stanów Zjednoczonych, gdzie ma nadzieję przemówić w Organizacji Narodów Zjednoczonych na temat problemów pokoju i wojny, sprawiedliwości i praw ludzkich ${ }^{11}$. Dużo miejsca poświęcił problemom pokoju. Ojciec Święty mówił o zagrożeniu do ludzkości, jakim było dla niego lekceważenie oraz niedostrzeganie przez rządzących niesprawiedliwości w kwestiach społecznych i polityce międzynarodowej. Jednocześnie zwrócił uwagę, iż w obliczu takich sytuacji nie wolno uciekać się do nienawiści, mordowania bezbronnych ludzi, a nade wszystko terroryzmu ${ }^{12}$. W sposób ewidentny tymi słowami papież odniósł się do sytuacji w Irlandii. Zresztą w całym słowie pasterskim można odnaleźć wiele odniesień do spraw irlandzkich. Nie mogło zabraknąć wątków związanych z historią chrystianizacji wyspy, działalnością św. Patryka, czy św. Olivera Plunketta ${ }^{13}$. Przedstawienie tych postaci nie było li tylko, kurtuazyjnym zabiegiem, mającym przedstawić, przypomnieć czy uhonorować ważnych irlandzkich świętych. Szczególnie postać Plunketta została uwypuklona, aby nadać kierunek dobrej, pokojowej drogi dwóm walczącym ze sobą irlandzkim stronom. Jan Paweł II zaznaczył, że wspominany

${ }^{5}$ Vide: Historia polityczna świata XX wieku 1945-2000, red. M. Bankowicz, Kraków 2004, s. 316-322.

${ }^{6}$ J. Moskwa, Droga Karola Wojtyły, t. 2. Zwiastun wyzwolenia 1978-1989, Warszawa 2011, s. 73-74.

7 Ibidem, s. 74.

${ }^{8}$ G. Weigel, Świadek nadziei. Biografia papieża Jana Pawła II, Kraków 2000, s. 435.

9 Z. Wójcik, Historia powszechna. Wiek XVI-XVII, Warszawa 2012, s. 441.

${ }_{10}$ J. Moskwa, op. cit., s. 74.

11 Jan Paweł II, Homilia wygłoszona w Drogheda - Pokój i pojednanie, [w:] Nauczanie papieskie, t. 2, cz. 2, R. 1979, red. E. Weron, A. Jaroch, Poznań 1992, s. 211.

${ }^{12}$ Ibidem.

13 Ibidem, s. 210. 
święty przed swoją męczeńską śmiercią przebaczył nieprzyjaciołom ${ }^{14}$. Miał być to wzór, za którym powinni podążać Irlandczycy, zarówno z południa, jak i Ulsteru. Jednak najbardziej dobitnym, dramatycznym i wielce emocjonalnym był bezpośredni, papieski apel do wiernych:

pragnę teraz zwrócić się do wszystkich mężczyzn i kobiet uwikłanych w przemoc. Na klęczkach was błagam, abyście zeszli ze ścieżek przemocy i wrócili na drogi pokoju ${ }^{15}$.

Korespondował z tym niesamowitym apelem, również inny, skierowany do sił politycznych, mających wpływ na losy Irlandii, aby nie tolerowały one aktów przemocy lub by nie próbowały ich usprawiedliwiać ${ }^{16}$. Pozostają jeszcze dwie istotne kwestie, na które trzeba zwrócić uwagę w wypowiedzi papieża. Pierwszą było jaskrawe nazwanie przemocy, będącej wielkim zagrożeniem dla pokoju, mianem zbrodni przeciwko ludzkości ${ }^{17}$. Drugi zaś problem, który można zdefiniować, jako proces eufemizacji, definiowany przez Ojca Świętego w następujący sposób:

aby nikt nie mógł nigdy nazywać morderstwa innym mianem jak morderstwo, aby spirali przemocy nie można było nigdy nadawać określenia nieuniknionej logiki lub koniecznych środków odwetu ${ }^{18}$.

Dnia 1 października 1979 r. papież wylądował w Bostonie. Na lotnisku, przywitała go pierwsza dama - Rosalynn Carter oraz Zbigniew Brzeziński - doradca prezydenta Jimmy'ego Cartera do spraw bezpieczeństwa narodowego. Taki skład delegacji powitalnej wynikał z tego, iż Watykan i Stany Zjednoczone nie miały oficjalnie stosunków dyplomatycznych ${ }^{19}$. Nawiązane one zostały dopiero 10 stycznia 1984 r., już za kadencji kolejnego prezydenta Ronalda Reagana ${ }^{20}$. Jednak, kiedy konklawe wybrało kardynała Wojtyłę na papieża (16 października 1978 r.), prezydent Carter, po konsultacji ze Zbigniewem Brzezińskim, mianował osobistego przedstawiciela przy Stolicy Apostolskiej, którym został Robert F. Wagner Jr. ${ }^{21}$ Podróż apostolska do USA była odpowiedzią Jana Pawła II na zaproszenie biskupów amerykańskich, do których dołączył się Jimmy Carter. Papież przebywał w Stanach

${ }^{14}$ G. Weigel, op. cit., s. 436.

15 Jan Paweł II, Homilia wygłoszona w Drogheda..., s. 214.

16 Ibidem, s. 215.

17 Ibidem, s. 213.

${ }^{18}$ Ibidem.

19 J. Moskwa, op. cit., s. 75.

20 M.L. Napolitano, Tajne akta Watykanu. Dyplomacja Kościoła - dokumenty i tajemnice, Kielce 2013, s. 337.

${ }^{21}$ Ibidem, s. 269. 
Zjednoczonych od 1 do 8 października22. Mimo niesprzyjającej pogody, nabożeństwo odprawione przez Ojca Świętego w Bostonie zgromadziło około dwóch milionów ludzi. Ciekawe jawi się to, iż tysiące wśród tego tłumu nie było osobami wierzącymi ${ }^{23}$.

Kulminacyjnym momentem wizyty apostolskiej w USA było wystąpienie na forum ONZ. 0 tym celu, będącym kluczowym elementem wizyty, papież wspominał już w Irlandii. Do Nowego Jorku Jan Paweł II przyjechał 2 października. Udał się do gmachu ONZ, gdzie przywitał go Kurt Waldheim ${ }^{24}$, sekretarz generalny ${ }^{25}$. Georg Weigel opisuje nastawienie, emocje i zachowanie gościa z jakim wszedł do budynku. Emanował dużą energią oraz spokojem, jego aparycja była bardzo radosna, ale jednocześnie wyczuwało się moc fizyczną oraz wnikliwość umysłu. Kiedy rozpoczął przemawiać, robił to z taką swobodą, którą obserwatorzy określali: tak jakby wykładał na Uniwersytecie w Lublinie ${ }^{26}$. Rzeczywiście, coś $\mathrm{w}$ takim określeniu może być, ponieważ, jego przemówienie trwało niemalże tyle co wykład akademicki, dobrze ponad godzinę ${ }^{27}$. Można jeszcze nadmienić, iż obradom sesji przewodniczył reprezentant Tanzanii, muzułmanin Salim Ahmed Salim, zwracający się do papieża słowami: Jego Świątobliwośćc ${ }^{28}$.

Pierwszą istotną rzeczą, którą zauważył papież, poświęcając jej wiele uwagi, była wspólnota interesów (związanych w głównej mierze z problematyką tytułową) i dążeń do nich pomiędzy Stolicą Apostolską a Organizacją Narodów Zjednoczonych. Watykan bardzo cenił sobie swój udział w pracach $\mathrm{ONZ}$, a ponadto nie przestał popierać jej zadań i inicjatyw mających na celu pokojowe współżycie i współpracę między narodami ${ }^{29}$. Kościół katolicki z racji swego przymiotu powszechności, jest z natury rzeczy uniwersalny, co sprawia, iż jego posłannictwo i działalność sama w sobie, jest: szczerze

22 Ibidem, s. 272.

${ }^{23}$ G. Weigel, op. cit., s. 437.

24 J. Moskwa, op. cit., s. 75.

${ }^{25}$ Kurt Waldheim - sekretarz generalny ONZ w latach 1972-1981. Następnie był prezydentem Austrii. Wokół jego osoby narosło wiele kontrowersji z okresu kiedy Austria była integralną częścią III Rzeszy. Szczególnie w trakcie kampanii prezydenckiej 1986 r., zarzucano mu, że był oficerem Wehrmachtu i brał udział w wywożeniu ludności jugosłowiańskiej, a także jako członek SA uczestniczył w akcjach antyżydowskich. Waldheim zaprzeczał temu, by brał udział w zarzucanych mu czynach. Znamienny jest fakt, iż jako prezydent Austrii swoją pierwszą wizytę zagraniczną odbył do Watykanu, gdzie Jan Paweł II przyjął go na osobistej audiencji. Vide: Historia polityczna..., s. 471, 604-605.

${ }^{26}$ G. Weigel, op. cit., s. 438.

27 J. Moskwa, op. cit., s. 76.

${ }^{28}$ Ibidem, s. 75.

${ }^{29}$ Jan Paweł II, Orędzie do Organizacji Narodów Zjednoczonych, Nowy Jork, 2.10.1979, „Chrześcijanin w Świecie. Zeszyty ODISS” 1979, nr 83, listopad, s. 76. 
zainteresowana istnieniem oraz działalnością Organizacji, która - jak wynika z jej nazwy - jednoczy i zespala narody i państwa ${ }^{30}$. W kwestii działalności samej Organizacji, została poruszona jeszcze jedna ważna z punktu widzenia papieskiej polityki rzecz, gdyż ONZ na wielu płaszczyznach realizowało, bądź dopełniało cele Kościoła. Były nimi współpraca w dziedzinie kultury, zdrowia, żywienia, pracy, czy pokojowego wykorzystania energii nuklearnej ${ }^{31}$. Ewidentnie te kwestie, zaliczające się do kluczowych wyróżników zachowania pokoju w społecznościach, leżały w gestii agend kościelnych.

Kilkukrotnie podkreślana podczas przemówienia była kluczowa dla Ojca Świętego Powszechna Deklaracja Praw Człowieka uchwalona przez ONZ 10 grudnia $1948 \mathrm{r}^{32}$ Dokument ten nazwany został prawdziwym słupem milowym na drodze do postępu moralnego ${ }^{33}$. Rozumieć to można jako ogromny krok ku pokojowej egzystencji narodów i państw, które ów akt skonstruowały i respektują. Stworzył on szansę na rozwój, gdyż ludzkość zrozumiała, że jeśli nie będzie się wzajemnie napadać i niszczyć to można się rozwijać i jednoczyćc ${ }^{34}$. Koniecznie trzeba mieć na uwadze, że wizyta papieża, zbiegała się z czterdziestą rocznicą wybuchu II wojny światowej. Stąd gość dobitnie i mocno wspominał ów konflikt, jako przykład, który nigdy nie może się powtórzyć. Nie zabrakło także w wystąpieniu wątków polskich. Prócz jasnego zasygnalizowania, iż wojna ta rozpoczęła się 1 września 1939 r. $^{35}$ napaścią Niemiec na Polskę, pojawiło się także odniesienie do niedawnej pielgrzymki Ojca Świętego do Ojczyzny (2-10 czerwca 1979 r.), ujęte jako wspomnienie $\mathrm{z}$ wizyty $\mathrm{w}$ byłem, niemieckim obozie zagłady w Oświęcimiu, czyli jednego z najboleśniejszych i najtragiczniejszych oraz najbardziej naznaczonych pogardą dla ludzkości miejsca ${ }^{36}$. Papież wyraźnie zaakcentował, że:

pamięć powinna być znakiem ostrzegawczym na drogach współczesnej ludzkości, aby raz na zawsze zniknęły wszystkie podobne obozy koncentracyjne na każdym miejscu ziemi ${ }^{37}$.

Poruszona została także, pewna dość drażliwa kwestia, która mogła być „zadrą w oku” dla niektórych przedstawicieli państw przy ONZ Jego Świątobliwość dodał bowiem, że stosowanie przemocy, tortur, czy ucisku,

\footnotetext{
30 Ibidem.

31 Ibidem, s. 77.

32 Ibidem, s. 78.

33 Ibidem, s. 79.

34 Ibidem.

35 Ibidem, s. 78.

36 Ibidem, s. 79.

37 Ibidem.
} 
rozumianego w różnej formie, a zatem również politycznego, jest kontynuacją zbrodniczych działań z tamtego okrutnego czasu. Staje się to tym gorsze i: boleśniejsze, jeśli dokonuje się pod pretekstem „bezpieczeństwa” wewnętrznego i konieczności utrzymania pozornego pokoju ${ }^{38}$. Śmiało można przypuszczać, iż tak odważne sformułowanie sprawy, było mocno niekomfortowe dla niektórych państw. Nie trzeba daleko szukać, by w ówczesnych realiach móc wymienić chociażby Związek Radziecki, czy państwa tzw. bloku wschodniego, a zatem również ojczyznę przemawiającego gościa. Pozostając przy wspomnianej przez papieża kwestii, łącząc ją z wielokrotnie sygnalizowaną w tekście Powszechną Deklaracją Praw Człowieka, należy dostrzec, iż dla papieża ten swoisty kamień węgielny, został zrodzony z niewyobrażalnego cierpienia milionów ludzi, które nie może pójść na marne ${ }^{39}$. Kończąc wątek kwestii II wojny, następca św. Piotra powtórzył za swym poprzednikiem, Pawłem VI, bardzo mocny i emocjonalny apel, nie tylko do osób słuchających go w gmachu ONZ, lecz do całej ludzkości: nigdy więcej wojny, nigdy więcej! Nigdy jedni przeciwko drugim, albo jedni ponad drugimi, ale zawsze jedni razem $z$ drugimi ${ }^{40}$. Jakże te słowa były wówczas aktualne, szczególnie, że wygłoszone jeszcze na gruncie amerykańskim, będącym jedną stron trwającej ówcześnie zimnej wojny.

Spoglądając na aspekt sprawy pokoju w kontekście zimnej wojny w przemówieniu papieża, widać, że miał on swoje miejsce odzwierciedlone w słowach Jana Pawła II. Jednak kwestia rywalizacji, najczęściej określanej przez Ojca Świętego mianem Wschód-Zachód, była tylko jednym z wątków polityki pokojowej doby zimnowojennej. Papież nie skupiał się na rozpatrywaniu problematyki sprawy światowego pokoju jedynie poprzez starcie dwóch antagonistycznych bloków. Sprawę tą widział bardzo szeroko, od pokoju na płaszczyźnie jednostek i rodziny, poprzez narody i dopiero potem różnego rodzaju bloki polityczno-militarne. Taki ogląd potwierdzają słowa odnoszące się do słuchających Jana Pawła II w siedzibie ONZ:

każdy z Was, Szanowni Panie i Panowie, jest przedstawicielem swojego państwa, poszczególnych systemów i struktur politycznych, ale nade wszystko jesteście przedstawicielami określonych jednostek ludzkich ${ }^{41}$.

Bezpośrednie nawiązanie do problemu ówczesnych realiów, miało swe odzwierciedlenie w zauważonym przez papieża zagrożeniu zbrojeniowym. Ojciec Święty był wielce zaniepokojony ciągłym wyścigiem zbrojeń, udosko-

\footnotetext{
38 Ibidem.

39 Ibidem.

40 Ibidem, s. 80.

${ }^{41}$ Ibidem, s. 77.
} 
nalaniem różnego rodzaju broni. Uważał, że wzrastająca produkcja broni świadczy o gotowości do wojny, a gotowość oznacza możliwość jej wywołania ${ }^{42}$. Pozytywnym aspektem zauważonym przez Jana Pawła II były negocjacje oraz wypracowane dokumenty, mające na celu redukcję zbrojeń ${ }^{43}$. Pomimo, że nie zostało to ujęte wprost a powyższa aprobata dla takich działań powiedziana była w sposób ogólnikowy, można wywnioskować, że papież miał na myśli w szczególności tzw. spotkania na szczycie pomiędzy przywódcą Związku Radzieckiego Leonidem Breżniewem, a prezydentami Stanów Zjednoczonych, czego rezultatem było wynegocjowanie porozumień rozbrojeniowych znanych jako SALT $\mathrm{II}^{44}$. Z orędzia bił także apel o potrzebny, energiczny wysiłek zmierzający $w$ kierunku likwidacji samych możliwości wywoływania wojen $^{45}$. Jak sądził papież, to ostatnie zadanie, powinno być realizowane przez wszystkie państwa świata, niezależnie od panujących w nich stosunków społeczno-ustrojowych. Ponadto rolę prewencyjną, zapobiegającą możliwości powstawania i wywoływania konfliktów miał wziąć na siebie Kościół, współpracując przy tym z ONZ. Zaskakujące wydaje się być, że kierowniczą rolę w tym zadaniu miała spełniać Organizacja Narodów Zjednoczonych. Jak to papież uzasadnił? Przywołał po raz kolejny Powszechną Deklarację Praw Człowieka, będącą dla niego narzędziem skierowanym przeciwko zarzewiom wojny, ponieważ kiełkują i dojrzewaja wszędzie tam, gdzie owe niezbywalne prawa człowieka sq naruszane ${ }^{46}$.

Zbrojenia zostały uwypuklone w zupełnie innym, interesującym kontekście. Chodziło o planowanie przyszłości przez państwa i kierujące nimi rządy w ujęciu następnych pokoleń. Jan Paweł II zaakcentował, że głównym zadaniem jest przekazywać pokój. Jak zauważył, nie można zostawić następnym pokoleniom spuścizny, w postaci wyścigu zbrojeń. $\mathrm{W}$ takim wypadku już w zarodku obarcza się je groźbą zbiorowej zagłady. Ojciec Święty, akcentując te słowa, odniósł się do mocarstw, które stały po dwóch przeciwnych sobie stronach w obliczu rywalizacji Wschód-Zachód ${ }^{47}$. Mówiąc o tym, wyraźnie wskazał, że to one, ze względu na swoją pozycję i możliwości, były

${ }^{42}$ Ibidem, s. 81.

${ }^{43}$ Ibidem.

${ }^{44}$ Nie weszły one w życie, chociaż zostały zaakceptowane zarówno przez przywódcę ZSRR Breżniewa, jak i prezydenta USA Cartera. Wynikało to z faktu, iż nie ratyfikował układu SALT II amerykański Kongres w odpowiedzi na radziecką interwencję w Afganistanie. W momencie orędzia Jana Pawła II w siedzibie ONZ sprawa tego porozumienia była otwarta, ponieważ papież przemawiał 2 października 1979 r., a interwencja radziecka rozpoczęła się pod koniec grudnia. Nie mogło być zatem mowy o przerwaniu wypracowanych ustaleń redukcyjnych w tym momencie.

${ }^{45}$ Ibidem.

${ }^{46}$ Ibidem, s. 81-82.

${ }^{47}$ Ibidem, s. 88. 
najbardziej odpowiedzialne za pokój oraz przekazywanie kolejnym pokoleniom odpowiedniej spuścizny. Przywołując starożytną maksymę Publiusa Flaviusa Vegetiusa Renatusa: si vis pacem, para bellum (chcesz pokoju, szykuj się do wojny) ${ }^{48}$, papież jednocześnie odciął się od niej. Stwierdził, że nie można wierzyć, iż nieustanne działania, nakierowane na wyścig zbrojeń, mogą służyć pokojowi na świecie ${ }^{49}$. Realizowanie wszelakich działań, według założeń przytoczonej starożytnej maksymy, to dla Jana Pawła II, reakcja jedynie na skutki. Ważniejsze, czyli przyczyny nie zostaną w ten sposób wyeliminowane, przez co ewentualne zagrożenie nowym konfliktem będzie wciąż obecne i realne ${ }^{50}$. Takie podejście wiązało się z określeniem samego słowa pokój, szerzej omawianego w orędziach na Światowy Dzień Pokoju. Z racji na analizę tych przemówień $w$ dalszej części artykułu, w tym miejscu można wspomnieć o tym, że dla następcy św. Piotra, pokój nie oznaczał jedynie braku wojny czy konfliktu. Był jednym z elementów składowych. Podobnie jak rywalizacja Wschód-Zachód stanowiła tylko jeden z wielu wątków sprawy pokojowej w okresie trwania zimnej wojny. Jan Paweł II przypomniał także inne konflikty za czasów jego pontyfikatu, w które Stolica Apostolska zaangażowała się, stając zawsze po stronie rozwiązania pokojowego. W orędziu wygłoszonym w ONZ papież odniósł się do sporu argentyńsko-chilijskiego ${ }^{51}$, problemu palestyńskiego, łączącego się z kwestią nie tylko relacji izraelsko-palestyńskich i dylematu Jerozolimy, lecz także związanego z nim zagadnieniem niezawisłości oraz integralności terytorialnej Libanu ${ }^{52}$.

Podczas przemówienia w siedzibie ONZ można odnieść wrażenie, że Jan Paweł II wystąpił w dwojakiej roli. Z natury rzeczy pierwszą z nich było bycie głową Kościoła Powszechnego. Nie brak w słowach zatem odniesień do katolików czy Boga. Druga z nich, to rola polityka. Papież, będąc jednocześnie głową państwa watykańskiego, miał do tego wszelkie prerogatywy. Te dwie płaszczyzny przenikały się ze sobą. Jednakże w omawianej sytuacji, wydaje się, iż bardziej widoczna była rola polityczna niż kościelna. Trzeba jednak uważać, by nie zwieść się wrażeniu, że papież wchodził tu w nie swoją rolę. Tak nie jest. Po pierwsze, co zostało wspomniane miał ku temu pełne prerogatywy, aby mówić o sprawach polityki. Ponadto, przemawiając

${ }^{48}$ M. Zięba OP, Ale nam się wydarzyło. O papieżu i Polsce, Kościele i świecie, Poznań 2013, s. 91.

49 Jan Paweł II, Orędzie do Organizacji..., s. 88.

${ }^{50}$ M. Zięba OP, op. cit., s. 91.

51 Watykan intensywnie zaangażował się na rzecz pokojowego rozwiązania wojny Argentyny z Chile o Kanał Beagle znajdujący się w obrębie Ziemi Ognistej. Konflikt rozpoczął się w styczniu 1979 r. Traktat pokojowy między Argentyną a Chile podpisano 23 stycznia $1984 \mathrm{r}$. Vide: Ibidem, s. 87.

${ }^{52}$ Jan Paweł II, Orędzie do Organizacji..., s. 80-81. 
do reprezentantów zgromadzonych w ONZ, takie stanowisko niewątpliwie było odpowiednie, właśnie ze względu na odbiorców. Wreszcie, nie brakowało stwierdzeń odwołujących się bezpośrednio do religii, czy to w formie prośby o modlitwę do Boga ${ }^{53}$, czy kwestii wartości duchowych ${ }^{54}$.

W swoim orędziu Ojciec Święty dodał jeszcze inne zagrożenia dla pokoju. Wymienił łamanie praw człowieka, zarówno $w$ wymiarze stosunków międzynarodowych, jak $w$ poszczególnych społeczeństwach ${ }^{55}$; napięcia ekonomiczne $^{56}$, przekształcające się nawet w neokolonializm ${ }^{57}$; niesprawiedliwość (również ta względem ducha) ${ }^{58}$; dyskryminację ze względu na pochodzenie, rasę, płeć, przynależność narodowq, wyznaniowa i przekonania polityczne $e^{59}$. Biorąc pod uwagę papieskie zalecenia, służące eliminacji zagrożeń dla pokoju, dominowało wśród nich jedno: troska o postęp i rozwój ludzkości ${ }^{60}$. Zdefiniowany został bardzo rozlegle, ponieważ nie polegał jedynie na rozwoju nauki i techniki, lecz nade wszystko pierwszeństwo miał rozwój wartości duchowych i moralnych ${ }^{61}$. Prymat odpowiednich wartości ma niebagatelny wpływ na odpowiednie używanie dóbr ziemskich i materialnych, przez co wpływa na podstawy sprawiedliwego pokoju ${ }^{62}$.

Na zakończenie swojego orędzia do Narodów Zjednoczonych Jan Paweł II skierował życzenie z jednoczesnym wstawiennictwem o pełną suwerenność dla wszystkich narodów, nawet tych które obecnie nie mogły się cieszyć jej pełnią oraz takich, którym ją zabrano przemocą. Powinny one wszystkie uczestniczyć w pracach ONZ, która to stanowiła dla papieża najwyższe forum pokoju i sprawiedliwości ${ }^{3}$.

Przemówienie chociaż miało charakter w większości dość ogólny, dzięki czemu mogło mieć formę przeglądową, zawierało diagnozę kryzysu ówczesnego świata, opierającego się na konfliktach pomiędzy blokami Wschodu a Zachodu, Północy i Południa (bogatych i biednych) oraz kapitalizmem i socjalizmem. Z tymi wszystkimi aspektami papież powiązał kryzys wartości

53 Vide: Ibidem, s. 89.

54 Vide: Ibidem, s. 83-84.

55 Ibidem, s. 85.

56 Ibidem.

57 Zostało to szerzej omówione przez papieża w encyklice Sollicitudo rei socialis, opublikowanej w 1987 r. Vide: Jan Paweł II, Enc. Sollicitudo rei socialis (30.12.1987), Wrocław 1997. Na tym przykładzie widać, że papieskie poglądy na pokój z pierwszego roku pontyfikatu, były obecne przez jego dalsze lata.

58 Idem, Orędzie do Organizacji..., s. 86.

59 Ibidem, s. 87.

60 Ibidem, s. 78.

61 Ibidem.

${ }^{62}$ Ibidem, s. 83.

${ }^{63}$ Ibidem, s. 89. 
moralnych i duchowych. W orędziu nie padły bezpośrednio takie zwroty jak komunizm, Związek Radziecki, czy Stany Zjednoczone, które mogłyby w sposób bardziej szczegółowy opisywać problem zagrożeń pokoju. Jednakże, jak opisuje George Weigel, posługując się relacją ambasadora Stanów Zjednoczonych przy ONZ, Daniela Patricka Moynihana, osoby na sali wiedziały, że w pewnych momentach, jak np. charakteryzujących wyścig zbrojeń, łamanie praw człowieka przez różne systemy polityczne, słowa papieża były adresowane do nich:

mogę zaświadczyć na podstawie moich obserwacji, że delegaci z Europy Wschodniej i Związku Sowieckiego dobrze wiedzieli, o czym papież mówi i po raz pierwszy w tej sali byli przestraszeni, a nie znudzeni ${ }^{64}$.

Amerykański biograf Jana Pawła II, zwrócił uwagę, że podczas wygłaszania orędzia na sali panowała cisza. Nikt nie przeszkadzał papieżowi w jego przemówieniu. Takie zachowanie oznaczać musiało, niezależnie od zgadzania się poszczególnych delegatów państw przy ONZ ze słowami Ojca Świętego, iż mieli oni szacunek do gościa, ponieważ przemawiał ktoś z kim trzeba się liczyć65.

Kolejna pielgrzymka Jana Pawła II do Stanów Zjednoczonych, ważna z punktu widzenia poniższego tekstu, miała miejsce w październiku $1995 \mathrm{r}$. Była to trzecia wizyta apostolska w tym kraju za pontyfikatu kardynała z Krakowa $^{66}$. Ojciec Święty przyleciał do USA 4 października 1995 r. Dzień później, miała miejsce wizyta w siedzibie Organizacji Narodów Zjednoczonych. Gość przemówił po raz drugi do Zgromadzenia Ogólnego ONZ. Tym razem wiele rzeczy zewnętrznych było innych niż szesnaście lat wcześniej. Papież był już schorowany, słabszy, widać było objawy Parkinsona ${ }^{67}$. Pomimo tego, siła jego słów była ogromna. Z pewnością miała na to wpływ pozycja Jana Pawła II oraz powszechny szacunek, który budził na świecie. Niewątpliwie, dla każdego mieszkańca globu, niezależnie zwolennika, czy przeciwnika, Jan Paweł II jawił się jako kluczowa postać XX w., odgrywająca wielką rolę

${ }^{64}$ G. Weigel, op. cit., s. 441.

${ }^{65}$ Ibidem, s. 442.

${ }^{66}$ Można też uznać ją za szóstą wizytę Jana Pawła II w Stanach Zjednoczonych, ponieważ w latach 80. papież był dwukrotnie na terytoriach zależnych, ale niepodległych od USA, gdzie zatrzymywał się podczas wizyt do innych państw, tj. Korea Południowa czy Tajlandia. W 1987 r. odbył kolejną, najdłuższą pielgrzymkę po Stanach Zjednoczonych, zaś w 1993 r., w Denver odbyły się VIII Światowe Dni Młodzieży. Vide: M. Jurzyk, Jan Paweł II w Stanach Zjednoczonych, „Niedziela w Chicago” 2005, nr 22; http://www.niedziela.pl/artykul/42105/nd/ Jan-Pawel-II-w-Stanach-Zjednoczonych, dostęp: 29.06.2017.

${ }^{67}$ G. Weigel, op. cit., s. 987. 
w historii, zarówno Kościoła, jak i całego świata ${ }^{68}$. Stąd słowa, wygłaszane przez niego zawsze budziły zainteresowanie.

Papieska wizyta oraz przemówienie w ONZ były swoistymi wyrazami uczczenia pięćdziesiątej rocznicy powstania Organizacji Narodów Zjednoczonych, o czym na samym początku swych słów Ojciec Święty wspomniał ${ }^{69}$. Warto przyjrzeć się, jakie elementy były zbieżne w wystąpieniu, zestawiając je z wcześniej analizowanym wystąpieniem z 1979 r., zaś co pojawiło się nowego. Jako zbieżne można wymienić podkreślanie roli ONZ w procesach pokojowych; interesy organizacji z celami i działalnością Kościoła oraz ich zgodna współpraca; zaakcentowanie doniosłej roli Powszechnej Deklaracji Praw Człowieka, zawierającej fundamentalne prawa człowieka, stanowiące element istnienia pokoju na świecie oraz w kontekście prawa do istnienia narodów; przypomnienie strasznej dla ludzkości II wojny światowej, jako przykład tego, co nigdy nie powinno powrócić; a przede wszystkim kwestie związane z prymatem rozwoju wartości duchowych. Wspólnym wyróżnikiem było wreszcie to, co najistotniejsze w dobie zimnej wojny - niepochamowane zbrojenia, których konsekwencją było, wciąż istniejące, zagrożenie wojną nuklearną ${ }^{70}$. Jednakże, z perspektywy 1995 r. problem ten nieco się oddalił $^{71}$, co nie oznaczało dla papieża, iż należałoby poprzestać w dalszych działaniach wychodzących naprzeciw wspomnianemu zagrożeniu. Pozostał po nim lęk o przyszłość i lęk przed przyszłościq̨ ${ }^{72}$.

Co pojawiło się nowego w papieskich przemyśleniach? Odpowiedź na to pytanie opisują słowa: u progu nowego tysiaclecia jesteśmy świadkami niezwykłego i globalnego przyspieszenia procesu dążenia do wolności ${ }^{73}$. Jan Paweł II scharakteryzował przemiany, które zaszły podczas tzw. jesieni narodów dokonanej w Europie Środkowo-Wschodniej, zapoczątkowanej w Polsce w 1989 r. Wydarzenia te zostały entuzjastycznie przyjęte przez Ojca Świętego. Korespondowały one z niezbywalnym prawem istnienia, podkreślonym w orędziu, które ujęte zostało w szerokim zakresie, wychodząc od prawa narodów do posiadania własnego, niezawisłego państwa oraz istnienia poszczególnej jednostki ludzkiej. Należy zaznaczyć jeszcze dwa elementy

68 Ibidem.

69 Jan Paweł II, Przemówienie do Zgromadzenia Ogólnego Organizacji Narodów Zjednoczonych, Nowy Jork, 5 października 1995 [w:] Przemówienia i homilie Ojca Świętego Jana Pawła II, red. M. Romanek, Kraków 2008, s. 40.

70 Ibidem, s. 41-47, 53.

71 Faktem jest, że w tym roku nie można już mówić o rywalizacji Związku Radzieckiego ze Stanami Zjednoczonymi, gdyż formalnie zimna wojna dobiegła końca.

72 Ibidem, s. 54.

73 Ibidem, s. 41. 
dostrzeżone przez papieża, które destabilizowały światowy ład. Pierwszy, ściśle związany z zimną wojną. Na przykładzie Ukrainy i Białorusi oraz państw kaukaskich, Jan Paweł II zwrócił uwagę na pogwałcenie praw narodów, przed i po II wojnie światowej. Dodatkowo nowo powstałe po $1945 \mathrm{r}$. demokracje ludowe Europy Środkowo-Wschodniej, zostały podporządkowane władzy Związku Radzieckiego, tracąc de facto własną suwerenność. Określił także, że takie uformowanie geopolityczne świata, spowodowało sztuczny podział Starego Kontynentu, nad którym zapanowała „zimna wojna”, w okresie której ludzkość żyła w nieustannym widmie nuklearnej zagłady. Dopiero po 1989 r., nadeszła realna nadzieja na pokój. Z tym zagadnieniem, współgrał drugi element destabilizujący światową harmonię. Papież nazwał go problemem współistnienia z odmiennościq. Chodziło tutaj o brutalne walki, do których doszło w Rwandzie oraz w Jugosławii, po jej rozpadzie $^{74}$. Szczególnie ten drugi problem Jan Paweł II przewidział w swej encyklice z 1991 r. Centesimus annus ${ }^{75}$.

Ostatnia część niniejszego artykułu będzie poświęcona, orędziom na Światowy Dzień Pokoju, które wygłosił Jan Paweł II w latach 1979-1991. Ustanowił go papież Paweł VI, specjalnym listem z 8 grudnia 1967 r., ustalając termin na pierwszy stycznia. W związku z tym witając kolejny $1968 \mathrm{r}$., przygotował i wygłosił pierwsze orędzie z okazji zainicjowanego przez siebie specjalnego dnia ${ }^{76}$. Od tego momentu, każdorazowo kolejni papieże 1 stycznia przemawiają w sprawie światowego pokoju, kontynuując dzieło Pawła VI. Bezpośrednio, po inicjatorze, zadanie to przejął Jan Paweł II. Jego orędzie, wygłoszone w 1979 r., było jeszcze koncepcyjnie uformowane przez poprzednika ${ }^{77}$. Wszystkie Światowe Dni Pokoju miały i do dzisiaj mają swoje hasło przewodnie, ogłaszane w połowie poprzedzającego roku. Jest ono wyznacznikiem treści i zagadnień podnoszonych w orędziach przez papieży. Analizując poszczególne tematy z kolejnych lat zaproponowanych przez Jana Pawła II w okresie zimnej wojny, wyłania się obraz wyraźnych wskazań i recept, którymi dzielił się papież, aby zapanował pokój na świecie. W tym świetle do stworzenia dogodnych warunków dla pokoju, potrzeba prawdy ${ }^{78}$,

${ }^{74}$ Ibidem, s. 41-44, 46-48.

${ }^{75}$ Vide: Idem, Enc. Centesimus annus (1.05.1991), Wrocław 2000.

761 stycznia - Światowy Dzień Pokoju; http://idziemy.pl/kosciol/1-stycznia-swiatowy-dzien-pokoju15857, dostęp: 30.06.2017.

${ }_{77}$ Nie chodzi tu o Jana Pawła I, który zmarł w trzydziestym trzecim dniu swojego pontyfikatu, ale o Pawła VI, który w połowie 1978 r. ogłosił hasło na XII Światowy Dzień Pokoju. Vide: Jan Paweł II, Osiagniemy pokój wychowując do pokoju. Orędzie na Światowy Dzień Pokoju 1.01.1979, „Chrześcijanin w Świecie. Zeszyty ODiSS” 1979, R. 11, nr 2 (74), luty, s. 92-101.

${ }^{78}$ Idem, Prawda siła pokoju. Orędzie Jana Pawła II na XIII Światowy Dzień Pokoju 1.01.1980; http://papiez.wiara.pl/doc/378707.Prawda-sila-pokoju-1980, dostęp: 6.06.2017. 
wolności ${ }^{79}$ - rozumianej również przez pryzmat religii ${ }^{80}$ oraz poszanowania mniejszości ${ }^{81}$. Fundamentem do budowy był dla papieża dialog ${ }^{82}$, który powinni podjąć wszyscy ludzie, z uwzględnieniem młodego pokolenia ${ }^{83}$. Sformułowawszy podstawy, papież zaproponował kolejne elementy będące drogami wiodącymi do pokoju. Były nimi rozwój i solidarnośćs ${ }^{4}$. Nie brakowało również orędzia zwracającego uwagę na trwającą walkę bloków w toczącej się zimnej wojnie. Dodatkowo papież połączył rywalizację Wschód-Zachód z innym podziałem Północ-Południe ${ }^{85}$. Podobny zabieg Jan Paweł II zastosował w encyklice Sollicitudo rei socialis. Zamykając kwestie tytułów, istnieje jeszcze jedna grupa, którą można by określić miarą duchowych rozważań o pokoju. Trzeba od razu zastrzec, iż sprawy religijne, bliskie papieżowi, znajdowały się w każdym orędziu. Tu były one punktem przewodnim, w którym Ojciec Święty wskazał, iż pokój to dar od Boga ${ }^{86}$. Żeby mógł zaistnieć $\mathrm{w}$ świecie, najpierw należało żyć $\mathrm{w}$ harmonii z Bogiem ${ }^{87}$, następnie także z sumieniem własnym oraz drugiego człowieka ${ }^{88}$.

Cechą wspólną wszystkich orędzi Jana Pawła II na Światowe Dni Pokoju jest ich struktura. Papież za każdym razem stosował wprowadzenie do

79 Idem, Orędzie na Światowy Dzień Pokoju. Chcesz służyć sprawie pokoju - szanuj wolność, [w:] Nauczanie papieskie, t. III/2 1980 (lipiec-grudzień), Poznań-Warszawa 1986, s. 811.

${ }^{80}$ Idem, Wolność religijna warunkiem pokojowego współżycia. Orędzie na XXI Światowy Dzień Pokoju 1.01.1988, „Chrześcijanin w Świecie. Zeszyty ODiSS” 1988, R. 20, nr 2 (173), luty, s. 118.

81 Idem, Poszanowanie mniejszości warunkiem pokoju. Orędzie Jana Pawła II na Światowy Dzień Pokoju 1.01.1989; http://papiez.wiara.pl/doc/378716.Poszanowanie-mniejszosci-warunkiem-pokoju-1989, dostęp: 8.06.2017.

82 Idem, Dialog na rzecz pokoju - wyzwaniem dla naszych czasów. Orędzie na XVI Światowy Dzień Pokoju 1.01.1983, „Chrześcijanin w Świecie. Zeszyty ODiSS” 1983, R. 15, nr 1 (112), styczeń, s. 106.

${ }^{83}$ Idem, Pokój i młodzi ida razem. Orędzie na XVIII Światowy Dzień Pokoju 1.01.1985, „Chrześcijanin w Świecie. Zeszyty ODiSS” 1985, R. 17, nr 3 (138), marzec, s. 88.

${ }^{84}$ Idem, Rozwój i solidarność: dwie drogi wiodqce do pokoju. Orędzie na XX Światowy Dzień Pokoju 1.01.1987, „Chrześcijanin w Świecie. Zeszyty ODiSS” 1987, R. 19, nr 1-2 (160-161), styczeń-luty, s. 229.

85 Idem, Pokój jest wartością, która nie zna podziałów na północ-południe, wschód-zachód: jest tylko jeden pokój. Orędzie na XIX Światowy Dzień Pokoju, „Chrześcijanin w Świecie. Zeszyty ODiSS" 1986, R. 18, nr 1-2 (148-149), styczeń-luty, s. 143.

86 Idem, Orędzie na XV Światowy Dzień Pokoju. Pokój - dar Boga powierzony ludziom, [w:] Nauczanie papieskie, t. 4/2, 1981 (lipiec-grudzień), Poznań 1989, s. 519.

87 Idem, Pokój z Bogiem Stwórca, pokój z całym stworzeniem. Orędzie Jana Pawła II na XXIII Światowy Dzień Pokoju 1.01.1990; http://papiez.wiara.pl/doc/378717.Pokoj-z-Bogiem-Stworca-pokoj-z-calym-stworzeniem-1990, dostęp: 17.06.2017.

${ }^{88}$ Idem, Poszanowanie sumienia każdego człowieka warunkiem pokoju. Orędzie Jana Pawła II na XXIV Światowy Dzień Pokoju 1.01.1991; http://papiez.wiara.pl/doc/378718. Poszanowanie-sumienia-kazdego-czlowieka-warunkiem-pokoju-1991, dostęp: 18.06.2017. 
tematu, który następnie rozwijał. Elementem spajającym było każdorazowe zwracanie się do państw, rządów, organizacji, aby wedle omawianej tematyki i zagadnień starały się działać na rzecz pokoju. Podobnie rzecz się miała z końcowymi fragmentami przemówień, które Ojciec Święty kierował do Chrześcijan, stawiając im zadania, wypływające z omawianej tematyki.

Jak łatwo wywnioskować, orędzia z okresu zimnej wojny są bardzo zróżnicowane. Problem pokoju był poruszany bardzo szeroko i rozlegle. Wiele rzeczy wyłania jako zbieżne z tym, co można było odczytać z encykliki Sollicitudo rei socialis. Z pewnością, poruszane kwestie stały się pomocne w późniejszym pisaniu tego rodzaju apostolskiego dokumentu. Trudno powiedzieć, aby teksty z interesującego okresu czasowego, były zdominowane przez konflikt Wschód-Zachód, chociaż sam autor dostrzegł, iż problem ten wiedzie prym, kiedy rozważa się go w kontekście zagrożenia dla pokoju ${ }^{89}$. Papież przedstawił dalej pewną szeroką gamę niebezpieczeństw i problemów pokoju w tym okresie, podobnie jak to uczynił w swoim wystąpieniu na forum ONZ, a następnie w przywołanej encyklice. Rywalizacja na linii USA-ZSRR była częścią składową całości zagadnienia widzianego przez Ojca Świętego, który poświęcił jej wiele akapitów. Warto przyjrzeć się, co konkretnego miał do powiedzenia w tej materii.

Pokój był dla Jana Pawła II sprawą najwyższej wagi ${ }^{90}$, która nigdy nie zatraciła swej aktualności. Ze względu na wciąż widoczny problem przemocy i wojny ${ }^{91}$. Rozwijając powyższy termin, papież odwołał się do Konstytucji Dogmatycznej o Kościele Gaudium et spes, którą wypracował Sobór Watykański II: pokój nie jest prostym brakiem wojny, ani też nie sprowadza się jedynie do stanu równowagi sił sobie przeciwstawnych ${ }^{92}$. Stanowił niewątpliwie pewien dynamiczny proces ${ }^{93}$, dzięki któremu osiąga się rozwój ${ }^{94}$. Z zagadnieniem tym, łączyła się również równowaga się. W odniesieniu do niej Ojciec Święty zaproponował zastąpienie jej zasadą wzajemnego zaufania ${ }^{95}$. Nie mogło zabraknąć spojrzenia religijnego, według którego przede wszystkim, należy zdawać sobie sprawę, iż pokój pochodzi od Boga ${ }^{96}$, czego dowodem były słowa Jezusa powiedziane po Zmartwychwstaniu: pokój Wam $^{97}$.

${ }^{89}$ Idem, Pokój i młodzi..., s. 93.

90 Ibidem, s. 88.

91 Ibidem.

${ }_{92}$ Idem, Poszanowanie mniejszości..., rozdz. 1; idem, Wolność religijna warunkiem..., s. 119.

${ }_{93}$ Ibidem.

${ }^{94}$ Idem, Pokój rodzi się z serca nowego. Orędzie na Światowy Dzień Pokoju 1.01.1984, „Chrześcijanin w Świecie. Zeszyty ODiSS” 1984, R. 16, nr 1 (124), styczeń, s. 136.

${ }^{95}$ Ibidem.

${ }^{96}$ Idem, Orędzie na XV..., rozdz. 4, s. 520.

${ }^{97}$ Ibidem, rozdz. 11, s. 525. 
Dla papieża konflikt związany z zimną wojną tylko pogłębiał aspiracje i żądze najważniejszych, światowych mocarstw, aby mogły rozgrywać własne interesy, przy pomocy grozy cyfr i brutalnej przemocy ${ }^{98}$. W takim układzie najbardziej odczuwały to kraje słabsze, gdyż to one w każdej sytuacji odczuwały kroki podejmowane przez głównych graczy na arenie międzynarodowej ${ }^{99}$. Taka, swoista "nadmierna interesowność" prowadziła do tworzenia się przeciwstawnych grup politycznych, ideologicznych oraz ekonomicznych. Przez to istniała idealna sytuacja do tworzenia i utrzymywania bloków, które dzieliły świat, stając na przeszkodzie do rozwoju i pokoju ${ }^{100}$. Świat był rozdarty, w którym dominowały podziały: Wschód-Zachód, Północ-Południe, przyjaciel-wróg ${ }^{101}$. Takie spostrzeżenia towarzyszyły papieżowi od początku pontyfikatu. Ojciec Święty nawoływał, aby antagonistyczne bloki, doszły wreszcie do przekonania, iż możliwy jest tylko jeden, prawdziwy pokój ${ }^{102}$, na rzecz którego należało prowadzić dialog ${ }^{103}$. Największym problemem zimnej wojny było widmo broni atomowej, bezpośrednio wynikające z rywalizacji Wschód-Zachód ${ }^{104}$. Według Jana Pawła II istniała tylko jedna możliwość zniwelowania lęku przed zagładą atomową - negocjacje. Miały się toczyć w celu ograniczenia arsenałów zbrojnych wielkich mocarstw ${ }^{105}$. Dodatkowo zostało postawione zadanie, by zasoby stosowane do wyścigu zbrojeń przeznaczono do zaspokojenia podstawowych potrzeb ludzkości ${ }^{106}$. Zamykając problem broni, papież apelował o kontrolowanie handlu nią, przenikającego wszelkie podziały ${ }^{107}$. W orędziach najwięcej miejsca Ojciec Święty poświęcił dialogowi i negocjacjom, potrzebnym zarówno dla pokoju, jak i rozwiązywaniu konfliktów, wśród których Wschód - Zachód był najważniejszym. Dialog wymagał wysiłku, którym dla przeciwnych stron miała być gotowość i otwartość do wysłuchania stanowiska antagonistycznej strony ${ }^{108}$, poparta szczerością intencji ${ }^{109}$. Napięcia, spory, konflikty domagają się rozwiązań na drodze słusznych negocjacji, a nie represji110. Papież ciekawie motywował konkurujące strony, aby wchodziły na drogi dialogu. Słusznie zauważył, że

\footnotetext{
${ }^{98}$ Idem, Osiągniemy pokój..., s. 93.

99 Ibidem.

100 Idem, Pokój jest wartościq..., rozdz. 2, s. 144.

101 Idem, Orędzie na XV..., rozdz. 2, s. 520.

102 Idem, Pokój jest wartościa..., rozdz. 1, s. 144.

103 Idem, Dialog na rzecz..., rozdz. 3, s. 107.

104 Idem, Pokój jest wartością..., rozdz. 2, s. 145.

105 Ibidem.

106 Ibidem, rozdz. 4, s. 147.

107 Ibidem, rozdz. 2, s. 145.

${ }^{108}$ Idem, Dialog na rzecz..., rozdz. 6, s. 109.

109 Idem, Prawda ..., rozdz. 8.

110 Idem, Osiągniemy pokój..., s. 94.
} 
właśnie okresy międzywojenne pozwoliły na stworzenie trwałych dzieł kultury, które sq chwała ludzkości ${ }^{111}$.

Jan Paweł II podkreślił, że wysiłki negocjacyjne muszą opierać się także na kwestiach rozbrojeniowych, które w relacji z rozwojem były najbardziej kluczowymi problemami ówczesnego świata ${ }^{112}$. Według papieża pokój nie zapanuje na świecie, dopóki siła militarna nie będzie wypierana na rzecz rozwoju, solidarności ${ }^{113}$ i wolności ${ }^{114}$. Bardzo mądre i oryginalne były przemyślenia z orędzia, mówiące o tym, że dialog, nawet kiedy wydawał się niemożliwy, ustępując zbrojnym konfrontacjom, w ostateczności gdy zwycięzcy osiągnęli zamierzone cele, a spustoszenie wojenne dobiegło końca, musiał wkroczyć, aby uregulować wszystkie sprawy ${ }^{115}$. Budowaniu pokoju musiały towarzyszyć nierozbieżne dążenia narodów. We wszystkich powyższych procesach niepoślednią rolę miał odgrywać Kościół oraz różne organizacje międzynarodowe na czele z ONZ ${ }^{116}$.

Ostatnią kwestią, wartą poruszenia jest pojęcie tzw. wojny sprawiedliwej. Błędnym, jest twierdzenie, że Jan Paweł II zupełnie odrzucał wojnę - dopuszczał ją tylko w jednym, możliwym zastosowaniu: w przypadku obrony swych wolności, przeciwko niesprawiedliwej agresji. Co więcej, uważał to nie tylko za prawo każdego człowieka, narodu czy państwa, a wręcz za obowiązek ${ }^{117}$. Mimo wszystko pokój był dla niego najważniejszą wartością, która nie znała podziałów na Wschód-Zachód, Północ-Południe, ponieważ wszędzie jest tylko jeden Lud, zjednoczony wola powszechnego pokoju ${ }^{118}$.

Podsumowując, należy powiedzieć, że Jan Paweł II rozumiał pokój w sposób holistyczny. Przenikało się przy tym wiele płaszczyzn, od najbardziej oczywistych, związanych z brakiem wojen, poprzez sprawy rozwoju ludzkości, skończywszy na kwestii religijnej. Pokój był dla papieża najważniejszą rzeczą, o którą cała ludzkość musi się starać. Największą odpowiedzialność $\mathrm{w}$ tej materii, miała klasa rządzącą, organizacje międzynarodowe, na czele z ONZ i Konferencją Bezpieczeństwa i Współpracy w Europie. Kościół powinien współpracować z owymi instytucjami, ponieważ światowy pokój był i jest jednym z nadrzędnych celów jego działalności. Kwestia rywalizacji Wschód-Zachód stanowiła znaczny przedmiot wystąpień i analiz papieskich,

111 Ibidem, s. 95.

112 Idem, Rozwój i solidarność..., s. 236.

113 Ibidem.

114 Idem, Orędzie na Światowy..., s. 812.

115 Idem, Dialog na rzecz..., rozdz. 5, s. 108.

116 Idem, Orędzie na XV..., rozdz. 10-11.

117 Ibidem, 12.

${ }^{118}$ Idem, Pokój jest wartościq..., rozdz. 7, s. 152. 
będąc jednym z czynników, blokujących światowy pokój. Szczególnie było to widoczne w wystąpieniu przed Zgromadzeniem Ogólnym ONZ z 1979 r. oraz w orędziach na Światowy Dzień Pokoju. Jak istotna, była to sprawa, świadczył fakt, że hasło na XIX edycję owego dnia, łączyło się z podziałami świata na Wschód-Zachód, Północ-Południe. Oprócz takich zagrożeń dla pokoju, Ojciec Święty wymieniał m.in. wyścig zbrojeń, z arsenałem nuklearnym na czele; niedorozwój świata (podział Północ-Południe); brak wolności i solidarności, wśród ludzi i narodów; czy terroryzm. Każdy z powyższych wyróżników był szerzej rozwijany w wystąpieniach papieskich. Przechodząc, do zaleceń papieskich w tytułowej sprawie, należy zaznaczyć przede wszystkim: dialog. Wydaje się on najważniejszy dla Jana Pawła II, ponieważ stanowił najistotniejsze narzędzie w kruszeniu podziałów i fundament w budowaniu pokoju, będącego udziałem każdego człowieka, narodu i państwa.

Koniecznym jest zauważenie, iż słowa papieża, jego analizy otaczającego go ówcześnie świata oraz szereg zaleceń były nie tylko trafne, lecz także szeroko akceptowane przez osoby słuchające wystąpień Jana Pawła II. Szczególnie można zauważyć, iż podczas przemówień Ojca Świętego w ONZ z jego słowami zdecydowanie zgadzali się wszyscy obecni ówcześnie w nowojorskiej siedzibie organizacji. Należy jednak postawić pytanie: co z tego wynikało? Otóż, niestety nic. Prócz wyrażania szerokiej aprobaty dla słów i działań papieża, czy Stolicy Apostolskiej nie szły za tym żadne dalsze działania państw. Skoro zarówno w przemówieniu z 1979, jak i 1995 r. papież ciągle widział wiele zagrożeń dla pokoju światowego, powtarzając kwestie sprzed kilkunastu lat, oznaczać to mogło jedno, iż prócz słów, pomysłów i zgód nie szły za tym żadne konkretne czyny przywódców światowych, aby idee pokoju wyrażane przez Jana Pawła II wcielać w życie. Podobnie miała się sprawa z orędziami z okazji Światowego Dnia Pokoju. Również i w tym przypadku słowa, apele, analizy, rozwiązania, czy propozycje papieskie nie były realizowane przez tych, na których w gruncie rzeczy spoczywać miał ciężar zapewniania pokoju oraz rozwoju na świecie. Jeszcze smutniejsze jawi się to, iż nawet dzisiaj gdyby wziąć do ręki analizowane wystąpienia papieża, to nadal bardzo duża ich cześć byłaby zasadna do realizacji. Co to oznacza? Wniosek z tego taki, iż szczytne, mądre i ciekawe idee Jana Pawła II (bo za takie były uważane, chociażby wśród gremium członków ONZ) w znacznej mierze nigdy nie zostały wcielone $\mathrm{w}$ życie, a świat zarówno ten z czasów pontyfikatu papieża-Polaka, jak i dzisiejszy nadal mógłby czerpać garściami z słów i nauk głoszonych przez Ojca Świętego. 


\section{BIBLIOGRAFIA}

\section{Źródła}

Jan Paweł II, Dialog na rzecz pokoju - wyzwaniem dla naszych czasów. Orędzie na XVI Światowy Dzień Pokoju 1 I 1983, „Chrześcijanin w Świecie. Zeszyty ODiSS” 1983, R. 15, nr 1 (112), styczeń.

Jan Paweł II, Enc. Centesimus annus (1.05.1991), Wrocław 2000.

Jan Paweł II, Enc. Sollicitudo rei socialis (30.12.1987), Wrocław 1997.

Jan Paweł II, Homilia wygłoszona w Drogheda - Pokój i pojednanie, [w:] Nauczanie papieskie, t. 2, cz. 2, 1979, red. E. Weron, A. Jaroch, Poznań 1992.

Jan Paweł II, Orędzie do Organizacji Narodów Zjednoczonych, Nowy Jork, 2.10.1979, „,Chrześcijanin w Świecie. Zeszyty ODISS" 1979, R. 11, nr 11 (83), listopad.

Jan Paweł II, Orędzie na XV Światowy Dzień Pokoju. Pokój - dar Boga powierzony ludziom, [w:] Nauczanie papieskie, t. 4/2, 1981 (lipiec-grudzień), Poznań 1989.

Jan Paweł II, Orędzie na Światowy Dzień Pokoju. Chcesz służyć sprawie pokoju - szanuj wolność, [w:] Nauczanie papieskie, t. 3/2, 1980 (lipiec-grudzień), Poznań-Warszawa 1986.

Jan Paweł II, Osiagniemy pokój wychowując do pokoju. Orędzie na Światowy Dzień Pokoju 1.01.1979, „Chrześcijanin w Świecie. Zeszyty ODiSS”, R. 11, nr 2 (74), luty 1979.

Jan Paweł II, Pokój i młodzi idq razem. Orędzie na XVIII Światowy Dzień Pokoju 1.01.1985, "Chrześcijanin w Świecie. Zeszyty ODiSS" 1985, R. 17, nr 3 (138), marzec.

Jan Paweł II, Pokój jest wartościq, która nie zna podziałów na północ-południe, wschód-zachód: jest tylko jeden pokój. Orędzie na XIX Światowy Dzień Pokoju, „Chrześcijanin w Świecie. Zeszyty ODiSS" 1986, R. 18, nr 1-2 (148-149), styczeń-luty.

Jan Paweł II, Pokój rodzi się z serca nowego. Orędzie na Światowy Dzień Pokoju 1.01.1984, „Chrześcijanin w Świecie. Zeszyty ODiSS” 1984, R. 16, nr 1 (124), styczeń.

Jan Paweł II, Pokój z Bogiem Stwórca, pokój z całym stworzeniem. Orędzie Jana Pawła II na XXIII Światowy Dzień Pokoju 1.01.1990. http://papiez.wiara.pl/doc/378717.Pokoj-zBogiem-Stworca-pokoj-z-calym-stworzeniem-1990

Jan Paweł II, Poszanowanie mniejszości warunkiem pokoju. Orędzie Jana Pawła II na Światowy Dzień Pokoju 1.01.1989. http://papiez.wiara.pl/doc/378716.Poszanowanie-mniejszosci-warunkiem-pokoju-1989

Jan Paweł II, Poszanowanie sumienia każdego człowieka warunkiem pokoju. Orędzie Jana Pawła II na XXIV Światowy Dzień Pokoju 1.01.1991. http://papiez.wiara.pl/doc/378718. Poszanowanie-sumienia-kazdego-czlowieka-warunkiem-pokoju-1991

Jan Paweł II, Przemówienie do Zgromadzenia Ogólnego Organizacji Narodów Zjednoczonych, Nowy Jork, 5 października 1995, [w:] Przemówienia i homilie Ojca Świętego Jana Pawła II, red. M. Romanek, Kraków 2008.

Jan Paweł II, Przemówienie przy pomniku pokoju, Hiroszima, 25 lutego 1981, [w:] Przemówienia i homilie Ojca Świętego Jana Pawła II, red. M. Romanek, Kraków 2008.

Jan Paweł II, Rozwój i solidarność: dwie drogi wiodące do pokoju. Orędzie na XX Światowy Dzień Pokoju 1 I 1987, „Chrześcijanin w Świecie. Zeszyty ODiSS” 1987, R. 19, nr 1-2 (160-161), styczeń-luty. 
Jan Paweł II, Wolność religijna warunkiem pokojowego współżycia. Orędzie na XXI Światowy Dzień Pokoju 1.01.1988, „Chrześcijanin w Świecie. Zeszyty ODiSS” 1988, R. 20, nr 2 (173), luty.

Prawda siła pokoju. Orędzie Jana Pawła II na XIII Światowy Dzień Pokoju 1.01.1980. http://papiez.wiara.pl/doc/378707.Prawda-sila-pokoju-1980

\section{Źródła internetowe}

1 stycznia - Światowy Dzień Pokoju. http://idziemy.pl/kosciol/1-stycznia-swiatowy-dzienpokoju15857

Honisz H., Święty Patryk - Europejczyk i patron Irlandii. https://www.deon.pl/religia/swiety-patron-dnia/art,296,swiety-patryk-europejczyk-i-patron-irlandii.html

Jurzyk M., Jan Paweł II w Stanach Zjednoczonych, „Niedziela w Chicago” 2005, nr 22. http://www.niedziela.pl/artykul/42105/nd/Jan-Pawel-II-w-Stanach-Zjednoczonych

\section{Opracowania}

Historia polityczna świata XX wieku 1945-2000, red. M. Bankowicz, Kraków 2004.

Moskwa J., Droga Karola Wojtyły, t. I-IV, Warszawa 2011.

Napolitano M.L., Tajne akta Watykanu. Dyplomacja Kościoła - dokumenty i tajemnice, Kielce 2013. Tyszkiewicz J., Czapiewski E., Historia powszechna XX wiek, Warszawa 2012.

Weigel G., Świadek nadziei. Biografia papieża Jana Pawła II, Kraków 2000.

Wójcik Z., Historia powszechna. Wiek XVI-XVII, Warszawa 2012.

Zięba M. OP, Ale nam się wydarzyło. O papieżu i Polsce, Kościele i świecie, Poznań 2013.

Michat Owczarek

\section{IDEA OF PEACE IN THE SPEECHES OF POPE JOHN PAUL II AT THE UNITED NATIONS FORUM FROM 1979-1995 AND THE MESSAGES FOR THE WORLD DAY OF PEACE FROM 1979-1991}

$\mathrm{T}^{\mathrm{T} a \mathrm{sin}}$

he Cold War was a time of very tense international relations. It will be interesting to answer the question: how did the Holy Father understand the world peace? How did he see a global situation? Was cold war present in the Holy Father messages? What should people do for the world peace? That problem was very important for the Catholic Social Teaching. Holy Father spoke of the world peace in many of his messages. John Paul II saw many aspects of that problem in his teaching.

The initiative of Paul VI, who invented the World Day of Peace, during which the Pope gave a specially prepared message, became very important. This work was continued by John Paul II and is cultivated to the present day. The Polish pope took the understanding of peace from Paul VI, saying that it is synonymous with development. In addition, the papal perception was distinguished by holism. 
In his speeches, the Pope clearly recognized that during the Cold War, the issue of world peace was permanently under threat. This fact was influenced by the divisions of the world into blocks, among which he distinguished: East-West and North-South.

As the main conception to master the world order, John Paul II saw dialogue. The dialogue was inseparably connected with another concept, which was a papal recipe for the deadly threat of nuclear war - negotiations. Unfortunately, apart from expressing broad approval for the words and actions of the Pope or the Holy See, no further actions of the states followed.

Keywords: peace, world peace, Catholic Social Teaching, John Paul II, cold war, pope, UN, World Day od Peace, message, speech, Holy See, USA, disarmament, encyclic, nuclear threat, Sollicitudo rei socialis, Centesimus annus, East-West, North-South. 